\title{
Synthesis and Study of the Properties \\ of Amphiphilic Poly-N-Vinylpyrrolidone with Terminal Thioalkyl Groups
}

\author{
Mikhail I. Shtilman*a, \\ Andrey N. Kuskova, Pavel P. Kulikova, \\ Anna L. Luss ${ }^{a}$, Anastasia V. Goryachaya ${ }^{a}$, \\ Vazha T. Dzhedzheya ${ }^{a}$ and Aristidis M. Tsatsakis ${ }^{b}$ \\ ${ }^{a}$ D.I. Mendeleyev University of Chemical Technology of Russia \\ 9 Miusskaya sq., Moscow, 125047, Russia \\ ${ }^{b}$ University of Crete \\ Voutes University Campus, Heraklion, Crete, GR-70013, Greece
}

Received 21.02.2019, received in revised form 30.05.2019, accepted 13.06.2019

\begin{abstract}
Poly-N-vinylpyrrolidone-based amphiphilic polymers, which can be used as drug carriers, were prepared by radical polymerization with a thiol-type chain transfer agent. The polymers did not contain sequences of hydrophilic and hydrophobic fragments in the main chain. Molecules contained only one hydrophilic and one hydrophobic fragment linked by a covalent bond. This facilitated the selforganization of macromolecules into micelles in aqueous media. The critical micelle concentration and its dependence on the molecular weight of the diblock copolymers and the length of the hydrophobic radical were determined.
\end{abstract}

Keywords: amphiphilic polymer, copolymers of $N$-vinylpyrrolidone, micelle, polymeric nanoparticle, polymeric surfactants.

Citation: Shtilman M.I., Kuskov A.N., Kulikov P.P., Luss A.L., Goryachaya A.V., Dzhedzheya V.T., Tsatsakis A.M. Synthesis and study of the properties of amphiphilic poly-N-vinylpyrrolidone with terminal thioalkyl groups. J. Sib. Fed. Univ. Biol., 2019, 12(3), 258-265. DOI: 10.17516/1997-1389-0300.

(C) Siberian Federal University. All rights reserved

This work is licensed under a Creative Commons Attribution-NonCommercial 4.0 International License (CC BY-NC 4.0).

* Corresponding author E-mail address: shtilmanm@yandex.ru

ORCID: 0000-0001-9219-5746 (Shtilman M.I.); 0000-0001-8140-2754 (Kuskov A.N.); 0000-0001-5221-7613 (Kulikov P.P.); $\overline{0000-0001-8539-0252}$ (Luss A.L.); 0000-0003-3824-2462 (Tsatsakis A.M.) 


\section{Синтез и исследование свойств \\ амфифильного поли-N-винилпирролидона \\ с концевыми тиоалкильными группами}

М.И. Штильман ${ }^{a}$, А.Н. Кускова, П.П. Куликов ${ }^{\text {a }, ~ А . Л . ~ Л у с с ~}{ }^{\text {a }}$ А.В. Горячая ${ }^{\text {a }}$ В.Т. Джеджея ${ }^{\text {, А.М. Тсатсакис }}$ а Российский химико-технологический университет им. Д.И. Менделеева Россия, 125047, Москва, Миусская площуадь, 9

${ }^{6}$ Университет Крита Греиия, GR-70013, Крит, Ираклион, Университетский кампус Воутес

Амфифильные полимеры на основе поли-N-винилпирролидона, которые можно использовать в качестве носителей лекарственных средств, были получень радикальной полимеризацией с передатчиком цеепи тиольного типа. При этом образуется полимер, который не содержит последовательности гидрофильных и гидрофобных фрагментов в основной иепи. Молекуль содержат только один гидрофильный и один гидрофобный фрагменты, связанные ковалентной связью. Это облегчает самоорганизациию макромолекул в мицелль в водных средах. Определена критическая концентрация мицеллообразования и ее зависимость от молекулярной массы диблок-сополимеров и длины гидрофобного радикала.

Ключевые слова: амфифильныйполимер, сополимеры $N$-винилпирролидона, мицелла, полимерная наночастийа, полимерные поверхностно-активные вещчества.

\section{Introduction}

The synthesis of nanoscale carriers of physiologically active compounds (PAC), which would enable the targeted transport of drugs to the affected organ, remains an urgent problem (Torchilin, 2001; Dhembre et al., 2011; Lu, Park, 2013). Of particular interest are nanoscale carriers capable, like viruses, of penetrating into living cells. The results of developments in pharmacology in recent decades have shown the low effectiveness of classical drugs in the treatment of diseases associated with genetically determined disorders, including oncological diseases. Gene therapy is a new, rapidly developing branch of medicine that uses methods of genetic engineering for treatment. It requires nanoscale polymeric carriers capable of delivering a wide variety of substances into the nuclei of living cells. Uptake by the cells usually occurs by phagocytosis, which severely limits the capabilities of such transport systems (Luss et al., 2018). These nanoscale carriers are not suitable for the vast majority of body cells, which absorb particles extremely slowly. When administered intravenously, most of the dose is deposited in rapidly phagocytizing cells of the liver, where it is degraded and, thus, inactivated. In addition, phagocytosis by 
cells inevitably leads to the release of PAC into lysosomes, followed by enzymatic destruction, which is accompanied by partial or complete loss of activity even of the portion of the dose that has passed through the liver. Therefore, of considerable interest is the possibility of the absorption of particulate carriers containing pharmaceutically active substances by cells without the use of endocytosis, which could ensure the delivery of chemically unstable PAC both directly into the cytosol and into the cell nuclei (Kabanov et al., 2002; Kuskov et al., 2010). Currently, liquid polymeric liposomes remain the only type of carrier capable of "circumventing" the mechanism of phagocytosis. However, due to the exchange of contents between the micelles and the surrounding liquid, they are not applicable in clinical practice (Torchilin, 2005; Alavi et al., 2017; Akbarzadeh et al., 2013). Creating new types of polymeric nanoscale drug carriers and identifying their patterns of penetration into living cells remains a very urgent task.

The purpose of the present study was to develop methods for the synthesis of polymeric nanoscale drug carriers with an external wall formed from surface-active amphiphilic polymers, which can penetrate into cells, bypassing the mechanism of phagocytosis.

\section{Materials and Methods}

\section{Materials}

N-vinylpyrrolidone (VP), 2,2-azobisisobutyronitrile (AIBN), and 1,4-dioxane were obtained from Acros (Geel, Belgium). Octadecylmercaptan, hexadecylmercaptan, decylmercaptan, and diphenylhexatriene were purchased from SigmaAldrich (MO, USA). All chemicals were used without further purification unless otherwise specified. All solvents and components of buffer solutions were of analytical grade and were used as received.

\section{Preparation of amphiphilic poly- $N$ -} vinylpyrrolidone

Well-washed and dried tubes with ground stoppers were loaded with $11.1 \mathrm{~g}(0.1 \mathrm{~mol})$ of $\mathrm{N}$-vinylpyrrolidone, the required amount of mercaptan as a chain transmitter (0.5-8 mol.\%), AIBN (1 wt.\%) as an initiator and $20 \mathrm{ml}$ of dioxane as a solvent. The tubes were purged with an inert gas (argon). The reaction was carried out with constant stirring at $70^{\circ} \mathrm{C}$ for 3 hours. After a predetermined time, the contents of the tubes were dissolved in distilled water and distilled on a rotary evaporator (IKA RV10 + HB10 Digital). After this, purification was carried out by dialysis against water (Slide-A-Lyzer ${ }^{\mathrm{TM}}$ Dialysis Flask, 2K MWCO, Thermo Scientific, USA) for 5 days. At the end of dialysis, the contents of the dialysis bags were dissolved in distilled water and evaporated on a rotary evaporator. The contents of the bottom residue were dried lyophilically and then in a vacuum gun. The resulting polymers were white powders that were soluble in water.

\section{Determination}

of the number average molecular weight

The number average molecular weight $\left(\mathrm{M}_{\mathrm{n}}\right)$ was determined by end-group analysis as described in (Kulikov et al., 2017).

The number average molecular weight was also determined by vapor osmometry. This method is used to determine the number average molecular weight of the polymer in relation to the saturated vapor pressure of the polymer solution and the vapor pressure of the pure solvent. Measurements of the average molecular weight of the VP polymers were carried out by the method of steam osmometry on a Knauer K-7000 osmometer (Germany) using polystyrene standards. The obtained data were processed using EuroOsmo 7000 software. 


\section{Determination of the critical micelle} concentration

The critical micelle concentration was determined by fluorescence spectroscopy. Diphenilhexatrien (DPHT) was used as a fluorescent probe. This method is based on the solubilization of hydrophobic DPHT with polymer particles. To do this, $4 \mathrm{mg}$ of DPHT was dissolved in $1 \mathrm{ml}$ of acetone. Then, the resulting solution was diluted with phosphate buffer (PBS) to a concentration of $0.5 \mu \mathrm{M}$ DPHT. Acetone was distilled off from the resulting solution by vigorous stirring under a vacuum. The resulting solution was added to samples containing the Amf-PVP solution in PBS to achieve a final DPHT concentration of $0.25 \mu \mathrm{M}$. After adding DPHT, samples were placed in a dry thermostat for 30 minutes. Fluorescence intensity measurements were carried out using a Hitachi 650-10S spectrofluorometer (Hitachi Instruments Inc., Japan) with an excitation wavelength $\lambda$ ex $=366 \mathrm{~nm}$ and an emission wavelength $\lambda \mathrm{em}=433 \mathrm{~nm}$.

\section{Results and discussion}

"Living" radical polymerization in the presence of a mercaptan-type chain transfer agent was used as a method of synthesis of surface-active end-capped copolymers of vinylpyrrolidone. Aliphatic mercaptans are widely used in polymerization processes as chain transfer agents, making it easy to control the molecular weight of the resulting oligomers. In addition, using poly-N-vinylpyrrolidone as an example, it was demonstrated that this reaction can be used to introduce the necessary terminal functional groups into end-capped copolymers. The high reactivity of mercaptans in the abovementioned radical processes initiated by AIBN is described in detail in a number of papers (e.g., Kulikov et al., 2017).

Surface-active polymers of $\mathrm{N}$-vinylpyrrolidone were obtained by radical polymerization of N-vinyl-2-pyrrolidone using AIBN as an initiator and aliphatic mercaptans as chain transfer agents. Three long-chain mercaptans - decylmercaptan, hexadecylmercaptan and octadecylmercaptan were used in the work (Fig. 1).

The molecular weight of the oligomers was controlled by changing the ratio of monomer to chain transfer agent in the reaction. With increasing amounts of mercaptan introduced into the reaction, the molecular weight of the resulting polymer decreased proportionally to the increase in the molar content of the thiol groups in the mixture. Thus, it can be varied in the range from 40 to $1 \mathrm{kDa}$. With a low content of chain transfer agent in the reaction, the $M_{n}$ depended on the length of the aliphatic thiol radical (Fig. 2). Reacting the long-chain octadecylmercaptan in an amount of 0.01 mol.\% yielded a high molecular weight polymer $\left(\mathrm{M}_{\mathrm{n}}=40 \mathrm{kDa}\right)$, while the use of an equivalent molar amount of the shorter decylmercaptan led to a lower molecular weight of $16 \mathrm{kDa}$. Hexadecylmecraptan occupied an intermediate

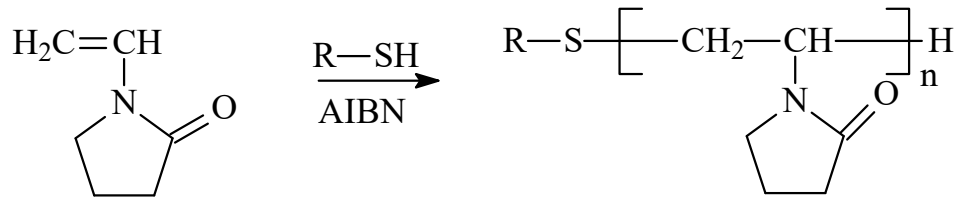

where $\mathrm{R}=\mathrm{C}_{18} \mathrm{H}_{37}, \mathrm{C}_{16} \mathrm{H}_{33}, \mathrm{C}_{10} \mathrm{H}_{21}$

Fig. 1. Schematic of the radical polymerization of $\mathrm{N}$-vinylpyrrolidone in the presence of a chain transmitter 


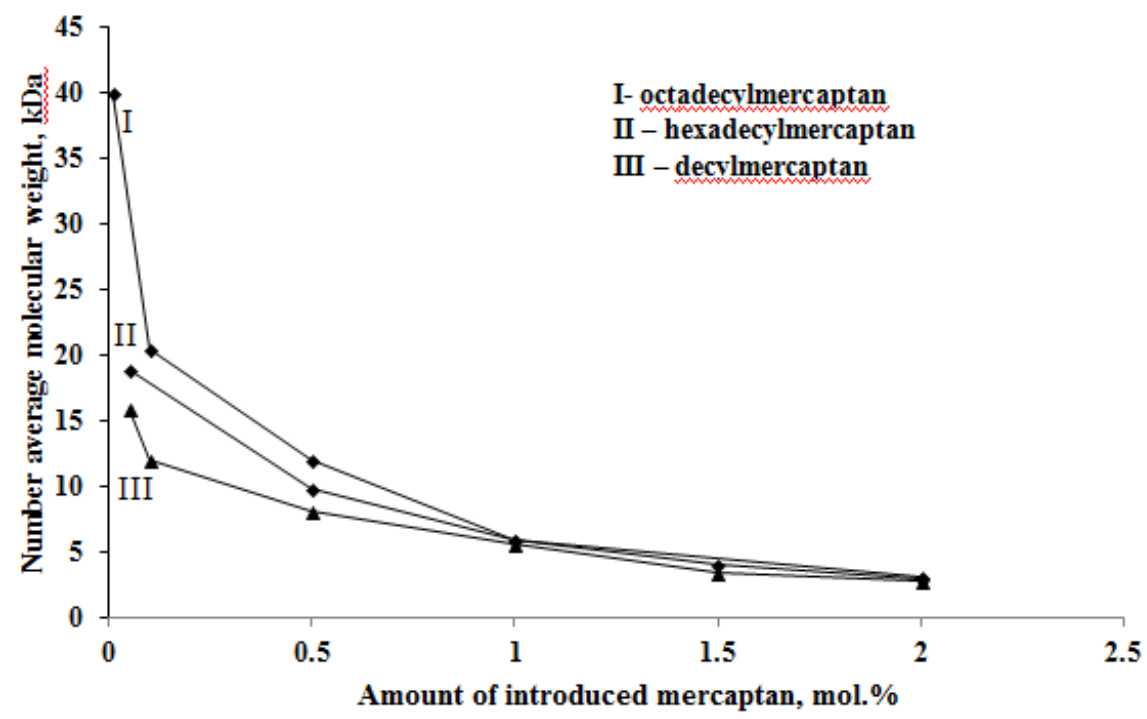

Fig. 2. Dependence of the number average molecular weight of end-capped poly-N-vinylpyrrolidone on the amount of I - octadecylmercaptan; II - hexadecylmercaptan; and III - decylmercaptan introduced into the system

position and produced a polymer with a molecular mass of $20 \mathrm{kDa}$ (Fig. 2). With an increase in the content of the chain transfer agent above 1 mol.\%, this effect was eliminated. Significant differences in the effectiveness of agents, which depend on the length of the aliphatic radical at low concentrations in the reaction medium, can be explained by increased hydrophobic interactions between amphiphilic polyvinylpyrrolidone and mercaptan as the length of the aliphatic radical of mercaptan increases. The effect disappears when the reaction medium is saturated with mercaptan and the sites for hydrophobic binding are exhausted.

Since the polymers are end-capped and contain both hydrophilic (poly-Nvinylpyrrolidone) and hydrophobic (aliphatic) fragments, aggregates of polymer molecules (micellar structures) are formed at a certain concentration (critical micelle concentration, $\mathrm{CMC}$ ). Due to the hydrophobic nature of the aliphatic fragment, in the micellar structure, these fragments are oriented inward to form a dense hydrophobic core. On the other hand, the hydrophilic fragment of PVP is oriented outward to form a stable hydrophilic shell. To determine the CMC of the synthesized polymers, the fluorescence emission spectra of DPHT in the presence of various concentrations of end-capped polymers were investigated. The method is based on DPHT beginning to emit light after incorporation into the micelles. DPHT was chosen as a model substance because of its hydrophobicity and very low solubility in water and because it can only fluoresce in the associated state. Due to these properties, DPHT is easily incorporated into the hydrophobic core and in this state has high-intensity fluorescence. Fig. 3 shows a typical graph of the dependence of the fluorescence intensity of DPHT on the concentration of end-capped polymer in the solution.

The data for determining the CMC of polymers with different hydrophobic moieties and different number average molecular weights are presented in Table 1.

The CMC of the end-capped polymers depends both on the length of the introduced 


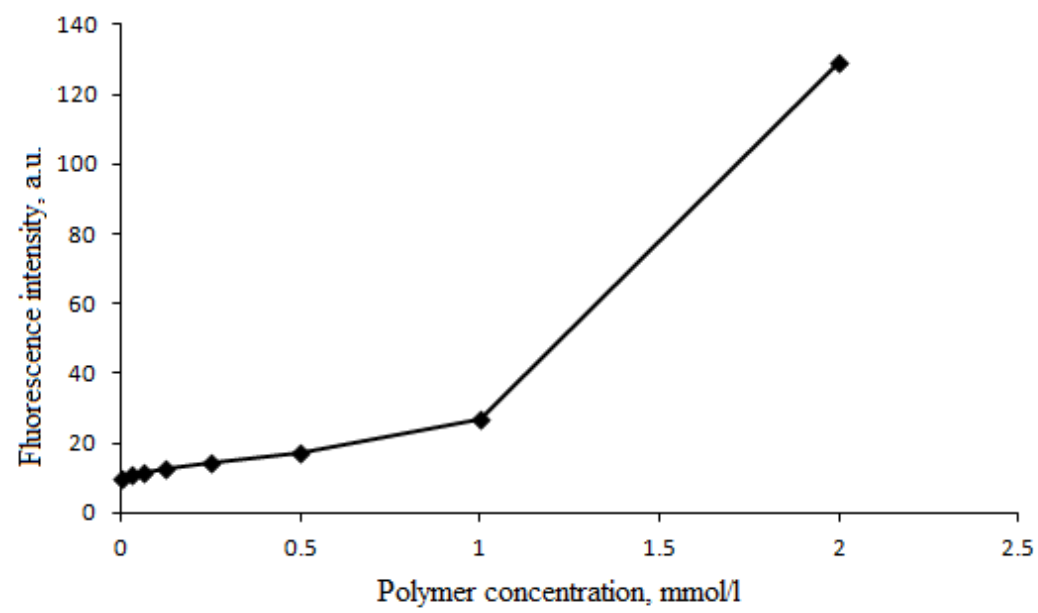

Fig. 3. Dependence of the fluorescence intensity of DPHT on the concentration of amphiphilic polymer (PVP-D-3500) at $25^{\circ} \mathrm{C}$

Table 1. Critical micelle concentration of end-capped polymers of $\mathrm{N}$-vinylpyrrolidone

\begin{tabular}{|c|c|c|c|}
\hline Polymer structure & $\begin{array}{c}\text { Number average } \\
\text { molecular weight, Da }\end{array}$ & Polymer code & $\begin{array}{c}\text { Critical micelle } \\
\text { concentration, mmol/1 }\end{array}$ \\
\hline PVP-S- $\mathrm{C}_{18} \mathrm{H}_{37}$ & 1000 & PVP-OD 1000 & 0.044 \\
\hline PVP-S- $\mathrm{C}_{18} \mathrm{H}_{37}$ & 3100 & PVP-OD 3100 & 0.054 \\
\hline PVP-S- $\mathrm{C}_{18} \mathrm{H}_{37}$ & 6050 & PVP-OD 6000 & 0.065 \\
\hline PVP-S- $\mathrm{C}_{18} \mathrm{H}_{37}$ & 12100 & PVP-OD 12000 & 0.175 \\
\hline PVP-S- ${ }_{18} \mathrm{H}_{37}$ & 20500 & PVP-OD 20000 & 0.339 \\
\hline PVP-S- $\mathrm{C}_{18} \mathrm{H}_{37}$ & 40000 & PVP-OD 40000 & 0.764 \\
\hline PVP-S- $\mathrm{C}_{10} \mathrm{H}_{21}$ & 3500 & PVP-D 3500 & 1.000 \\
\hline PVP-S- $\mathrm{C}_{16} \mathrm{H}_{33}$ & 3500 & PVP-HD 3500 & 0.242 \\
\hline
\end{tabular}

aliphatic radical and on the number average molecular weight of the polyvinylpyrrolidone fragment of the molecule. The introduction of hydrophobic substituents of increasing length into polymers with the same molecular weight leads to a steady decrease in the CMC. Therefore, the presence of an end-capped thiooctadecyl radical in PVP with a mean molecular weight of $\mathrm{M}_{\mathrm{n}}=3.5 \mathrm{kDa}$ results in the production of a surface-active copolymer with a $\mathrm{CMC}=0.054 \mathrm{mmol} / \mathrm{l}$, while the analogous product with a thiodecyl terminal substituent has a CMC 20 times higher $(1 \mathrm{mmol} / \mathrm{l})$, and use of a thiohexyl terminal substituent gives a CMC 4 times higher (0.2 mmol/l) (Fig. 4).

In all studied samples, regardless of the length of the thioaliphatic terminal radical, the $\mathrm{CMC}$ increases with an increase in the number average molecular weight of the polyvinylpyrrolidone fragment, but the dependence is complex (Fig. 5). Up to $\mathrm{M}_{\mathrm{n}}=6 \mathrm{kDa}$, the critical micelle concentration is linearly related to the molecular weight. A further increase in $M_{n}$ leads to a more dramatic increase in $\mathrm{CMC}$, and a bend is observed on the graph. A further increase in molecular weight, 


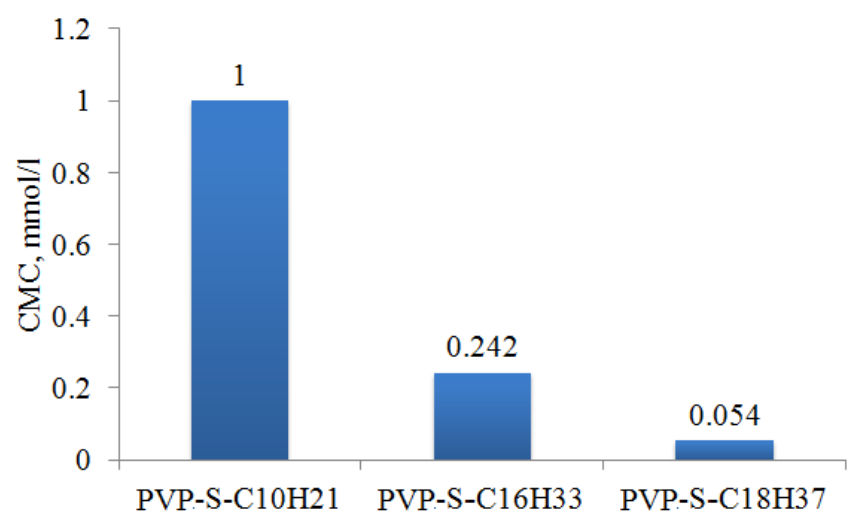

Fig. 4. CMC for samples with different terminal groups $\left(M_{n}=3500\right)$

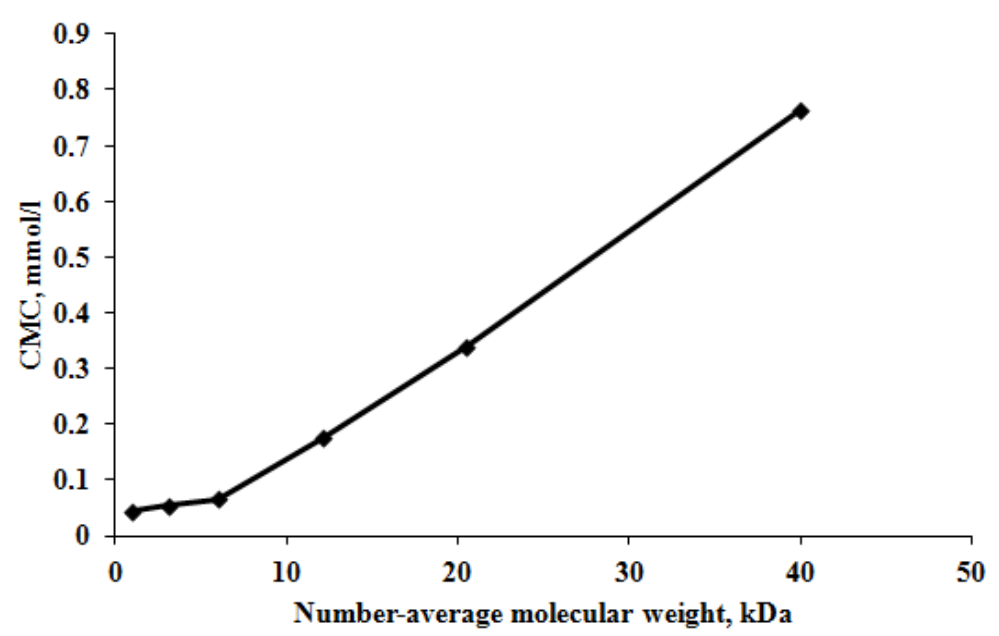

Fig. 5. Dependence of the CMC of amphiphilic polymer with thiooctadecyl end groups on its number average molecular weight

up to $\mathrm{M}_{\mathrm{n}}=40 \mathrm{kDa}$, leads to a linear increase in CMC.

This dependence is described for polysaccharides containing hydrophobic substituents in the side chain (Dyatlov et al., 2014; Dyatlov et al., 2015). The phenomenon is explained by a change in the nature of the intermolecular interactions with an increase in the molecular weight of the hydrophilic part of the polymer above the kinetic segment length and the shielding of hydrophobic groups. Hence, the formation of micelles does not occur.

\section{Conclusion}

Radical polymerization of N-vinylpyrrolidone using long-chain mercaptans as chain transfer agents produced end-capped amphiphilic copolymers of controlled molecular weight, which exhibited surface-active properties and were suitable for producing nanoscale drug carriers. The chemical structure, molecular weight characteristics, and surface-active properties of the synthesized block copolymers were studied. The surface-active properties of the polymers were determined by the molecular weight and length of the aliphatic radical. 


\section{References}

Akbarzadeh A., Rezaei-Sadabady R., Davaran S., Joo S.W., Zarghami N., Hanifehpour Y., Samiei M., Kouhi M., Nejati-Koshki K. (2013) Liposome: classification, preparation, and applications. Nanoscale Research Letters, 8: 102

Alavi M., Karimi N., Safaei M. (2017) Application of various types of liposomes in drug delivery systems. Advanced Pharmaceutical Bulletin, 7(1): 3-9

Dhembre G.N., Moon R.S., Kshirsagar R.V. (2011) A review on polymeric micellar nanocarriers. International Journal of Pharma and Bio Sciences, 2(2): 109-116

Dyatlov V.A., Kruppa I.S., Mamaeva S.A., Kutergina I.Yu., Gumnikova V.I., Grebeneva T.A., Kireev V.V. (2014) Change of polysaccharide molecular-weight distribution and fraction homogeneity after periodate oxidation. Chemistry of Natural Compounds, 50(6): 973-977

Dyatlov V.A., Gumnikova V.I., Grebeneva T.A., Kruppa I.S., Rustamov I.R., Kireev V.V., Maleev V.I. (2015) Study of the chemical structure of dialdehyde carboxymethyl cellulose produced by periodate oxidation under different conditions. International Polymer Science and Technology, 42(4): T19-T26

Kabanov A.V., Batrakova E.V., Alakhov V.Y. (2002) Pluronic block copolymers as novel polymer therapeutics for drug and gene delivery. Journal of Controlled Release, 82(2-3): 189-212

Kulikov P.P., Kuskov A.N., Goryachaya A.V., Luss A.N., Shtil'man M.I. (2017) Amphiphilic polyn-vinyl-2-pyrrolidone: Synthesis, properties, nanoparticles. Polymer Science, Series D, 10(3): 263268

Kuskov A.N., Voskresenskaya A.A., Goryachaya A.V., Shtilman M.I., Spandidos D.A., Rizos A.K., Tsatsakis A.M. (2010) Amphiphilic poly-N-vinylpyrrolidone nanoparticles as carriers for nonsteroidal, anti-inflammatory drugs: Characterization and in vitro controlled release of indomethacin. International Journal of Molecular Medicine, 26(1): 85-94

Lu Y., Park K. (2013) Polymeric micelles and alternative nanonized delivery of vehicles for poorly soluble drugs. International Journal of Pharmaceutics, 453(1): 198-214

Luss A.L., Kulikov P.P., Romme S.B., Andersen C.L., Pennisi C.P., Docea A.O., Kuskov A.N., Velonia K., Mezhuev Ya.O., Shtilman M.I., Tsatsakis A.M., Gurevich L. (2018) Nanosized carriers based on amphiphilic poly-N-vinyl-2-pyrrolidone for intranuclear drug delivery. Nanomedicine, 13(7): 703-715

Torchilin V.P. (2001) Structure and design of polymeric surfactant-based drug delivery systems. Journal of Controlled Release, 73(2-3): 137-172

Torchilin V.P. (2005) Recent advances with liposomes as pharmaceutical carriers. Nature Reviews Drug Discovery, 4(2): 145-160 